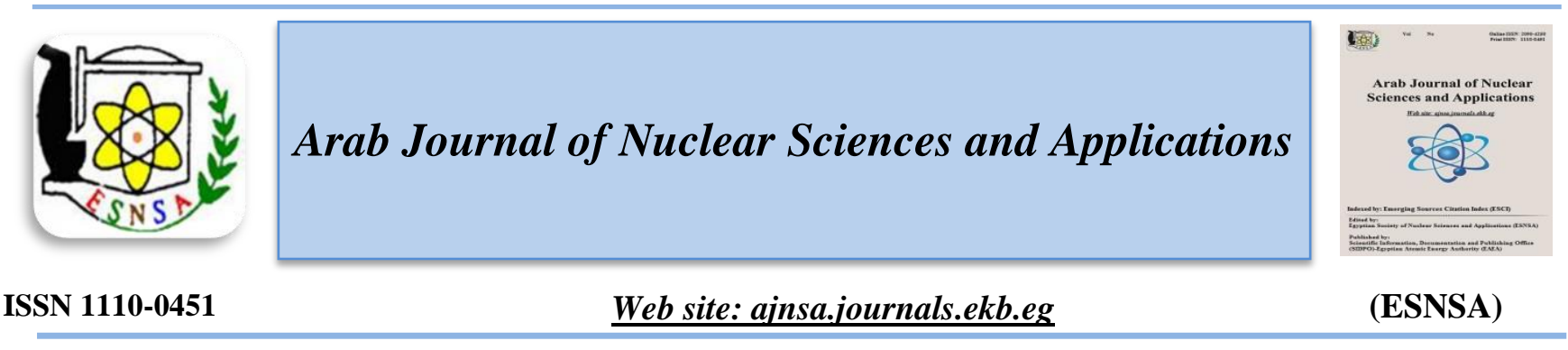

\title{
Gamma - Radiation-induced reaction of Sulfuric Acid with Silica Gel: A Novel Method for the Formation of sulfonic Acid-Functionalized Silica $\left(\mathrm{SiO}_{2}-\mathrm{SO}_{3} \mathrm{H}\right)$
}

\author{
Kh. A. Sife - Eldeen and H. M. Hosni \\ Radiation Chemistry Department, National Center for Radiation Research and Technology \\ Atomic Energy Authority, Cairo, Egypt
}

Received $3^{\text {rd }}$ March 2020 Accepted $14^{\text {th }}$ Sept. 2020

\begin{abstract}
The radiation-induced reaction of sulfuric acid with silica gel (SG) was carried out using $r$-radiation from a ${ }^{60} \mathrm{Co}$ source at room temperature and, its mechanism were suggested. The formation of sulfonated $\mathrm{SG}\left(\mathrm{SiO}_{2}-\mathrm{SO}_{3} \mathrm{H}\right)$ was confirmed by IR, thermal analysis (TGA/ DSC). Elemental analysis and morphological structure of treated $\mathrm{SG}\left(\mathrm{SG}_{\text {treated }}\right)$ was investigated by scanning electron microscopy (SEM). According to the comparison of the SEM images of SG and $\mathbf{S G}_{\text {treated }}$, it seems that irradiation of SG in the presence of sulfuric acid leads to partial segmentation of SG particles. The IR spectra of the treated silica $\left(\mathbf{S G}_{\text {treated }}\right)$ is different from that of the $\mathbf{S G}$. Where, peaks related to the presence of sulfunic group are observed, as well as shifts of SG peaks due to treatment. Moreover, TGA/ DSC of SG $_{\text {treated }}$ is different from that of SG. Elemental analysis reveals that particle size of SG affects the S/O \% value, where $\mathrm{SG}_{\text {treated }}$ with $>0.16 \mathrm{~mm}-0.2 \mathrm{~mm}$ particle size has the maximum value. Also, $\mathrm{S} / \mathrm{O} \%$ value, of $>0.16 \mathrm{~mm}-0.2 \mathrm{~mm}$ SG particle size, increased, linearly, with absorbed dose up to $80 \mathrm{kGy}$ and then decresed at higher doses.
\end{abstract}

Keywords: Silica gel; Sulfuric acid; Gamma radiation; Sulfonic acid - functionalized silica

\section{Introduction}

Chemical modification of SG surface has been growing in the recent years [1]. SG have been Chemically modified, i.e. functionalized, via surface hydroxyl groups as anchor points [2-4]. Generally, immobilized reagents on inorganic solid supports show several advantages such as ease of recyclability and purification of the catalyst [5,6]. Many conventional attempts have been conducted for the synthesis of solid sulfonic acid functionalized silica $\left(\mathrm{SiO}_{2}-\mathrm{SO}_{3} \mathrm{H}\right)$, such as the reaction of chlorosulfonic acid with $\mathrm{SG}$ [4,7-13]. In this view, several types of $\mathrm{SiO}_{2}-\mathrm{SO}_{3} \mathrm{H}$ have been synthesized and applied in catalyzing chemical transformations and organic synthesis [6,11,13]. The use of $\mathrm{SiO}_{2}-\mathrm{SO}_{3} \mathrm{H}$ as a catalyst in organic synthesis has attracted great interest. Therefore, $\mathrm{SiO}_{2}-\mathrm{SO}_{3} \mathrm{H}$ catalyst was used for alkylation [14], esterification [15], nitration [16], acetylation [17] formylation [18], heterocyclic synthesis [9,19], and Sulphonation [20]. Moreover, $\mathrm{SiO}_{2}-\mathrm{SO}_{3} \mathrm{H}$ was used for heavy metal ions removal from aqueous solutions [21], such as, uranium recovery from granite leach solutions [22]. Moreover, modification of surfaces with superhydrophilic/moieties [4] is important in fabrication of electrical conducting materials. Therefore, a new proton-conducting membrane was prepared by the addition of $\mathrm{SiO}_{2}-\mathrm{SO}_{3} \mathrm{H}$ [23], where, $\mathrm{SiO}_{2}-\mathrm{SO}_{3} \mathrm{H}$ can improve the proton conductivity of the Nafion/SiO2, which can be used in proton exchange membrane fuel cell

Corresponding author: sifekhdr@hotmail.com

DOI: 10.21608/ajnsa.2020.25092.1333

CScientific Information, Documentation and Publishing Office (SIDPO)-EAEA 
(PEMFC) [24]. Moreover, the incorporation of $\mathrm{SiO}_{2}-\mathrm{SO}_{3} \mathrm{H}$ with high surface area in an organic polymer matrix enhances the water uptake and conductivity properties [25]. Although many studies have been published on classical synthesis of $\mathrm{SiO}_{2}-\mathrm{SO}_{3} \mathrm{H}$, no data on its radiation-induced formation was available. Therefore, the present work aims to study the $\gamma$-Radiation-induced formation of silica bonded -sulfonic acid by radiolysis of sulfuric acid in the presence of silica gel.

\section{Experimental}

Different particle size samples $(\leq 0.16 \mathrm{~mm}$, $>0.16 \mathrm{~mm}-0.2 \mathrm{~mm},>0.2 \mathrm{~mm}-\leq 0.5 \mathrm{~mm})$, of $\mathrm{SG}$ were obtained by sieving (60-100 meshes-Merk) after washing by double distilled water and drying at $100 \mathrm{C}^{\circ}$. Sulfuric acid $95-97 \%$ from Merk was used without further purification. In $20 \mathrm{ml}$ bottle, $10 \mathrm{ml}$ sulfuric acid was added to $2 \mathrm{~g}$ of $\mathrm{SG}$ (preheated at 100 for 12hours).

Samples were irradiated at ambient temperature using $\gamma$-rays from a 60 -Co source of NCCRT at dose rates in the range $1.11 \mathrm{kGy} / \mathrm{h}$. After irradiation, the SG were filtered, thoroughly washed with double distilled water and soaked therein overnight to remove the residual (non bonded) sulfuric acid, the samples were then dried in oven at $100^{\circ} \mathrm{C}$ to constant 12 hours.

\section{Infrared Spectroscopy FT-IR}

FTIR spectra (from $4000-400 \mathrm{~cm}^{-1}$ ) of the SG before and after radiolytic treatment (irradiation with Sulfuric acid) were obtained at room temperature with a BRUKER Vertex70 spectrometer (Billerica, MA, USA) at a resolution of $2.0 \mathrm{~cm}^{-1}$.

\section{Thermogravimetric analysis (TGA/ DSC)}

Thermogravimetric analysis (TGA/ DSC) of the SG samples before and after radiolytic treatment was performed using thermo-gravimetric analyzer instrument (Simultaneous DSC/ TGA- SDT Q600 USA). About $10 \mathrm{mg}$ of powder samples was heated in an alumina holder in air or nitrogen (flow rate $100 \mathrm{~mL} / \mathrm{min}$ ). Analysis was carried out in the temperature range from $20{ }^{\circ} \mathrm{C}$ to $1000{ }^{\circ} \mathrm{C}$ at a heating rate of $20^{\circ} \mathrm{C} / \mathrm{min}$.

Scanning electron microscopy (SEM) and elemental analysis (EDX)
Surface morphological study of the prepared samples was carried out using a Scanning Electron Microscope (SEM) (JEOL-JSM-5400-Japan), operated at an accelerating voltage of $30 \mathrm{keV}$. In addition, qualitative and quantitative elemental analysis of the samples under investigation was performed using an Energy Dispersive X-ray analyzer (EDX) (OXFORD-ISIS-UK) attached to the above-mentioned model of the JEOL scanning electron microscope.

\section{RESULTS AND DISCUSSION}

The possibility of SG surface sulfonation via radiolysis of $\mathrm{SG}$ in the presence of concentrated sulfuric acid was characterized by studying IR spectra, TGA, DSC thermograms and SEM and EDX elemental analysis.

\section{SEM micrographs of $S G$ and $S G_{\text {(treated) }}$}

Scanning electron micrographs of SG and SG (treated) samples at magnification x100 are shown in Fig. (1).

From the micrographs (Fig.1A) and (Fig.1B), it can be observed that both images of the particles have different morphological nature, where SG (treated) (Fig.1B) sample has a rougher surface than that of the untreated SG (Fig.1A). This difference may be due to the irradiation of SG in the presence of $\mathrm{H}_{2} \mathrm{SO}_{4}$. The micrograph of $\mathrm{SG}_{\text {(treated) }}$ (Fig.1B), reveals the presence of many segments as compared to SG (Fig. 1A). This can be assigned to the rupture of SG particles due to irradiation in the presence of $\mathrm{H}_{2} \mathrm{SO}_{4}$, where, $\mathrm{Si}-\mathrm{O}$ bonds can be ruptured by radicals such as $\mathrm{H}$ atoms [25a], which can be formed during radiolysis. Reformation of ruptured $\mathrm{Si}-\mathrm{O}$ can be hindered via the reactions of the free radicals of ruptured $\mathrm{Si}-\mathrm{O}$ with other irradiation produced radicals.

\section{Effect of SG particle size}

EDX was used to determine the elemental percentage of $\mathrm{S}$ and $\mathrm{O}$ for samples with different SG particle size (ps) irradiated $(80 \mathrm{kGy})$ with concentrated sulfuric acid. Table1 illustrates, beside the $\mathrm{S} \%$ and $\mathrm{O} \%$, the $\mathrm{S} / \mathrm{O} \%$. It is obvious that the maximum $\mathrm{S} / \mathrm{O} \%$ ratio was observed in the presence of SG ps " $>0.16 \mathrm{~mm}-0.2 \mathrm{~mm}$ ". The minimum $\mathrm{S} / \mathrm{O} \%$ ratio was observed in the case of ps $((\leq 0.16 \mathrm{~mm})$ sample, although, ps " $\leq 0.16 \mathrm{~mm}$ " corresponds to the highest surface area in this study. This can be attributed to that, the higher the number of silanol groups present on the surface the 
more hydrophilic the silica surface is. Therefore, in the case of the smallest particle size $(\leq 0.16 \mathrm{~mm})$ silica particles, spontaneously, adhere together by the cohesive forces (hydrogen bonding) [26]. As the ps increased $(>0.16 \mathrm{~mm}-0.2 \mathrm{~mm})$, adherence of the SG particles decreased, where the cohesive forces and consequently, the mutual particles attraction become lower relative to that of " $\leq 0.16 \mathrm{~mm}$ " [26]. Consequently, $\mathrm{S} / \mathrm{O} \%$ reaches the maximum value in the presence of $\mathrm{ps} ">0.16 \mathrm{~mm}$ $0.2 \mathrm{~mm}$ ". Further increase in ps $(>0.2 \mathrm{~mm}-$ $\leq 0.5 \mathrm{~mm}$ ) will lead to slight decrease in $\mathrm{S} / \mathrm{O} \%$. This behavior can be related to the increase of the overall surface area of the SG particles as their particle size decreases, consequently, the available $\mathrm{OH}$ groups, for reaction with $\mathrm{H}_{2} \mathrm{SO}_{4}$, will decrease [26]. Moreover, the pore diameter is proportional to the particle size and varies inversely with specific surface area. Therefore, the smallest particle size has the highest surface area, and consequently the smallest pore diameter [26]. Consequently, in the case of the smallest pore diameter, the diffusion of the, large, sulfuric acid molecules may be hindered and consequently their reactions with silanol groups present in the pores.

\section{Effect of absorbed radiation dose}

It was observed previously that the maximum $\mathrm{S} / \mathrm{O} \%$ of irradiated $\mathrm{SG} / \mathrm{H}_{2} \mathrm{SO}_{4}$ system was obtained with " $>0.16 \mathrm{~mm}-0.2 \mathrm{~mm}$ " ps. Consequently, such particle size $(>0.16 \mathrm{~mm}$ $0.2 \mathrm{~mm}$ ) was used in the study of the effect of absorbed radiation dose on $\mathrm{S} / \mathrm{O} \%$ of $\mathrm{SG} / \mathrm{H}_{2} \mathrm{SO}_{4}$ system. Figure (2) illustrates the increase in the S/O\% as absorbed dose increased up to79.6 $\mathrm{kGy}$. The $\mathrm{S} / \mathrm{O} \%$ decreases with further dose increase.

\section{Thermo-gravimetric analysis (TGA)}

The thermal behavior of $\mathrm{SG}$ and $\mathrm{SG}_{\text {(Treated) }}$ was studied by thermo-gravimetric/differential thermal analyses (TGA/ DSC). Although, several workers studied TGA/DSC of SG indirect bonded to sulfonic groups [27, 28], no data were published on the thermal analyses of SG directly bonded to sulfonic groups. In the current study, thermal degradation was investigated in the range $30-$ $1000{ }^{\circ} \mathrm{C}$ under air (oxidative atmosphere) or nitrogen to study/ approve the properties , and formation of sulfonated SG in the current study. The TGA thermograms in air (Fig.3) show two characteristic decomposition stages. It is obvious that that allover the run the residual weight of $\mathrm{SG}_{\text {(treated) }}$ is higher than that of SG.

In fig.(3), upon comparing the first weight loss (around $100^{\circ} \mathrm{C}$ ) in $\mathrm{SG}$ and $\mathrm{SG}_{\text {(treated) }}$ thermograms, due to physically bonded water on the surface [27,31-33], it is clear that there is a difference in the amount of water loss. Where, the weight loss is higher in the case of SG $(16 \%)$, than $\mathrm{SG}_{\text {(treated) }}$ (14\%). Which can be attributed to the superhydrophilicity of $\mathrm{SG}_{\text {(treated) }}$ surface due to the attached sulfonic groups $[33,34]$. Therefore, the holding efficiency (hydrogen bonding strength) of water is higher in the $\mathrm{SG}_{\text {(Treated) }}$ and, consequently, lose of water will be less than in the case of SG. Moreover, it is observed that the weight loss stage of $\mathrm{SG}_{\text {(Treated) }}$ is shifted to higher temperature $\left(102^{\circ} \mathrm{C}\right)$ relative to that of $\mathrm{SG}\left(95^{\circ} \mathrm{C}\right)$. This shift indicates that the $\mathrm{SG}_{\text {(treated) }}$ has a higher hydrophilic property, i.e., water strongly adsorbed. Moreover, in the thermogram of $\mathrm{SG}_{(\text {Treated })}$, it was observed that, weight loss region in the temperature range of 200 to $600^{\circ} \mathrm{C}$, can be due to the oxidative decomposition of sulfonic acid group $[27,29,30,35]$. Also, the weight loss in temperature range " 200 to $600^{\circ} \mathrm{C}$ ' can be due to water loss caused by the strong hydrogen bonding among water molecules, and the sulfonic acid groups attached to silica gel [27]. It should be mentioned that the 'strongly bound water' around the sulfonic groups (hydrated water) can remain attached with the sulfonic group until its thermal decomposition [36]. This process is nearly completed up to about $200-600^{\circ} \mathrm{C}[35,37]$. At higher temperature $\left(700-1000{ }^{\circ} \mathrm{C}\right)$, the slow, continuous weight loss was, probably, due to the condensation of vicinal silanol groups leaving siloxane groups [38]. Moreover, it is obvious that the final residue, at $1000{ }^{\circ} \mathrm{C}$, is higher in the case of $\mathrm{SG}_{\text {(Treated) }}$ relative to that of $\mathrm{SG}$ (fig.3) which, can be attributed to the product of entraestrification reaction between sulfonic groups and vicinal silanol groups.

Figure (4) illustrates differences of DSC thermograms of $\mathrm{SG}$ and $\mathrm{SG}_{\text {(Treated) }}$ in air. The thermogram of $\mathrm{SG}_{\text {(Treated) }}$ shows three endothermic peaks $(1,2,4)$ and one exothermic peak (3). Endothermic peak (1) is related to the desorption of physically bonded water [31] and confirms the initial weight loss observed in the TGA analysis. Also, peak (2) can be related to strongly bonded water to sulfonic groups [31], as well as, silanol groups. Exothermic peak (3) can be assigned to 
oxidative decomposition of sulfonic groups. It should be mentioned that peak (3) is slightly shifted to higher temperature relative to corresponding exothermic peak in SG thermogram. Endothermic peak (4) may point to a chemical reaction(s) between remaining sulfonic and silanol groups

Figure (5) reveals the effect of gas atmosphere on the thermal degradation of $\mathrm{SG}$ and $\mathrm{SG}_{\text {(Treated) }}$. It is obvious that weight loss of $\mathrm{SG}_{\text {(Treated) }}$ is higher than that of SG when the thermal analysis is carried in $\mathrm{N}_{2}$ gas. Interestingly, this situation is the reverse of that in air (Fig.3), in which weight loss of $\mathrm{SG}$ is higher than that of $\mathrm{SG}_{\text {(treated) }}$. This important observation confirms the reaction of sulfuric acid with SG. Moreover, in air, it seems that $\mathrm{O}_{2}$ may, either oxidizes, stabilizes, or enhances its reaction of sulfonic groups with other species, such as silanol groups. Where, in nitrogen atmosphere, such reaction may be hindered.
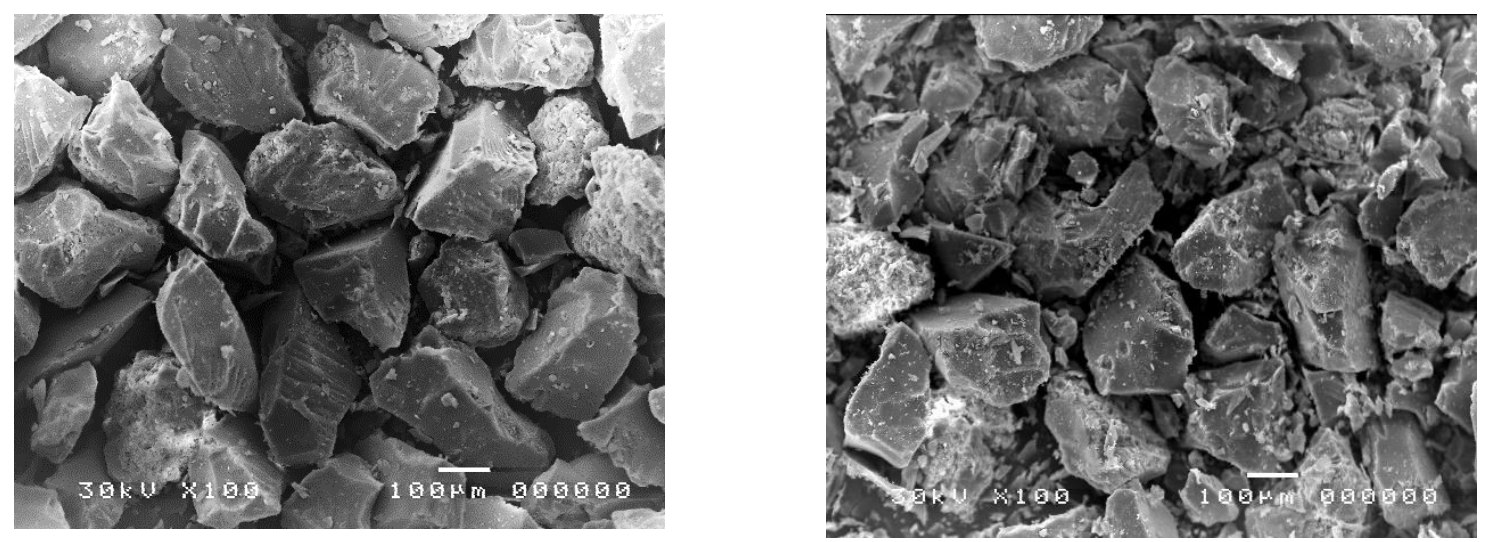

Fig. (1): SEM micrographs of (A) SG (left) and (B) SG (treated) (right)

Table (1): Effect of SG particle size on the S\%, $0 \%$, and S/O\%

\begin{tabular}{cccc}
\hline ps & S\% & O\% & S/O\% \\
\hline$\leq 0.16 \mathrm{~mm}$ & $\mathbf{0 . 2}$ & $\mathbf{2 . 3}$ & $\mathbf{8 . 7}$ \\
$>0.16 \mathrm{~mm}-0.2 \mathrm{~mm}$ & $\mathbf{0 . 4}$ & $\mathbf{2 . 0}$ & $\mathbf{2 0 . 0}$ \\
$>0.2 \mathrm{~mm}-\leq 0.5 \mathrm{~mm}$ & $\mathbf{0 . 3}$ & $\mathbf{1 . 8}$ & $\mathbf{1 6 . 7}$ \\
\hline
\end{tabular}

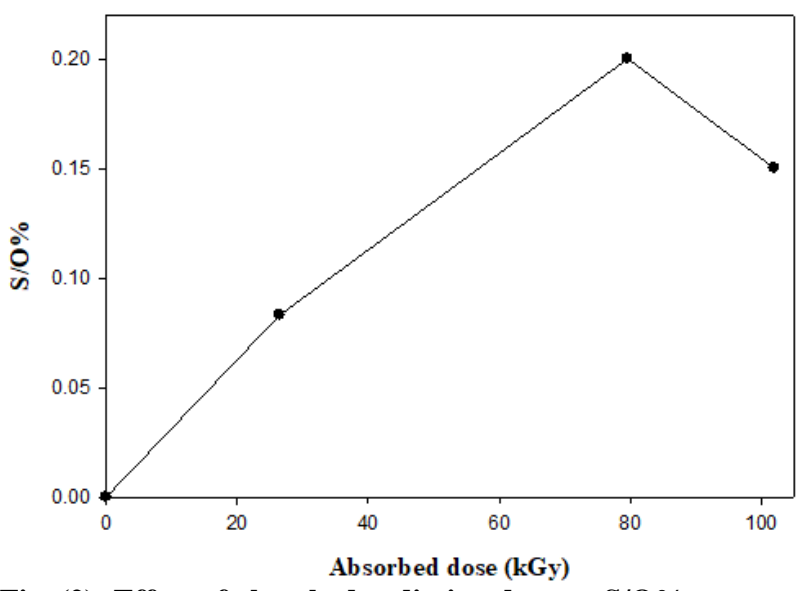

Fig. (2): Effect of absorbed radiation dose on S/O\% (according to EDX surface analysis), dose rate $=1.11 \mathrm{kGy} / \mathrm{h}$.

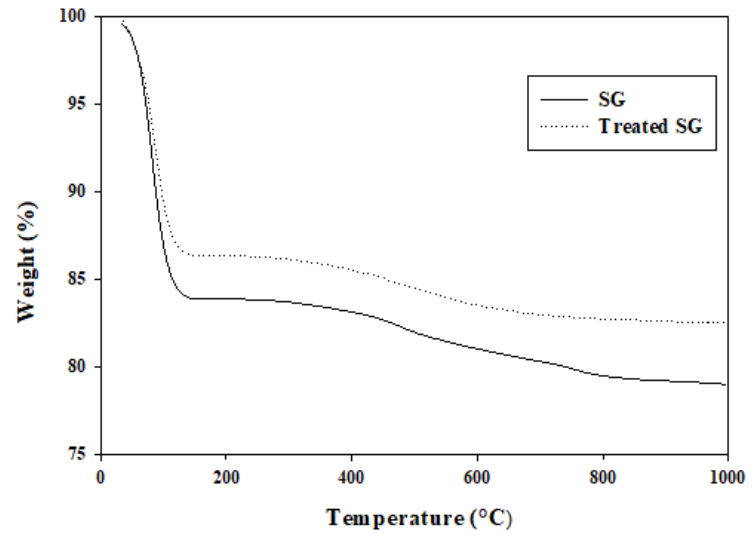

Fig. (3): Thermograms of $S G-, S_{\text {treated }} \ldots . .$. from RT up to $1000^{\circ} \mathrm{C}$, in air $\left(20^{\circ} \mathrm{C} / \mathrm{min}\right)$. 


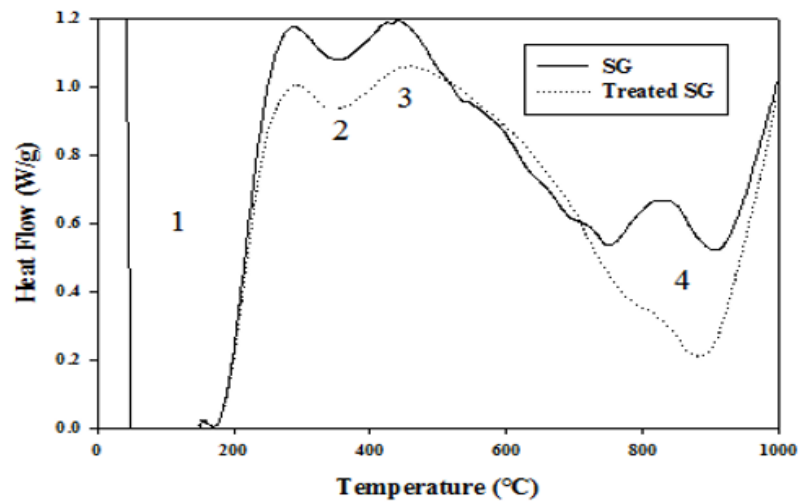

Fig. (4): DSC thermograms of $S G$ and $S G_{(\text {Treated) }}$ in air.

\section{Infrared spectroscopic analysis (FT-IR)}

The FT-IR spectrums of the SG and $\mathrm{SG}_{\text {treated }}$ were recorded in the frequency range of $4000-500 \mathrm{~cm}^{-1}$ in order to verify the presence of sulfonic groups on the SG surface. Assignments of the main bands are based on literature values [39-41]. Generally, it is observed that there are differences in IR peaks shape (hights) as well as shift in IR peaks location in the IR spectra of $S G$ and $S_{\text {treated, }}$ specially, in finger print region. These shifts of peaks locations indicate a chemical modification of the surface of SG. Moreover, the appearance of some peaks indicates the sulfonation of the SG surface. So, Fig.(6) illustrates partial spectra (450$620 \mathrm{~cm}^{-1}$ ) of SG (A) and $\mathrm{SG}_{\text {treated }}$ (B). In these spectra, a slight red shift of peaks at 456.26 ( $\mathrm{Si}-\mathrm{O}$ $\mathrm{Si}$ out of plane bending/ symmetric stretching ) $[42,43]$ and $560.25 \mathrm{~cm}^{-1}$ (Si-O-Si stretching modes) [43] was observed, while, peak at $606.59 \mathrm{~cm}^{-1}$, due to $\mathrm{Si}-\mathrm{O}$ bending[44] was blue shifted to 611 . $44 \mathrm{~cm}^{-1}$. The red shift of the peak at $456.26 \mathrm{~cm}^{-1}$ (Si-O-Si out of plane bending) to $455.43 \mathrm{~cm}^{-1}$, and peak at $560.25 \mathrm{~cm}^{-1}$ to $557 \mathrm{~cm}^{-1}$ in $\mathrm{SG}_{\text {treated }}$, can be attributed to the presence of sulfonic groups attached to SG. Also, the blue shift $\left(606.59 \mathrm{~cm}^{-1} \rightarrow\right.$ 611. $44 \mathrm{~cm}^{-1}$ ) can be related to the bending vibrations of sulfonic acid groups . Where, the $\mathrm{SO}_{2}$ scissors absorb in the range 520-610 cm-1 [45]. Also, it seems that the peak at 606.59 (SG), due to Si-O- bending [44] is blue shifted to 611.44 due to sulfonic acid groups substitution $-\mathrm{Ve}$ inductive effect (-I)[46]. Moreover, Table 2 and Fig.(6) shows that the peak height ratio (557/455) in spectrum $B(0.089)$ is higher than that of $(560 / 456)$ in spectrum $\mathrm{A}(0.058)$. Also, peak height ratio (606/455) in spectrum $A(0.092)$ is higher than that of (611/455) in spectrum B (0.072) (Fig.6).

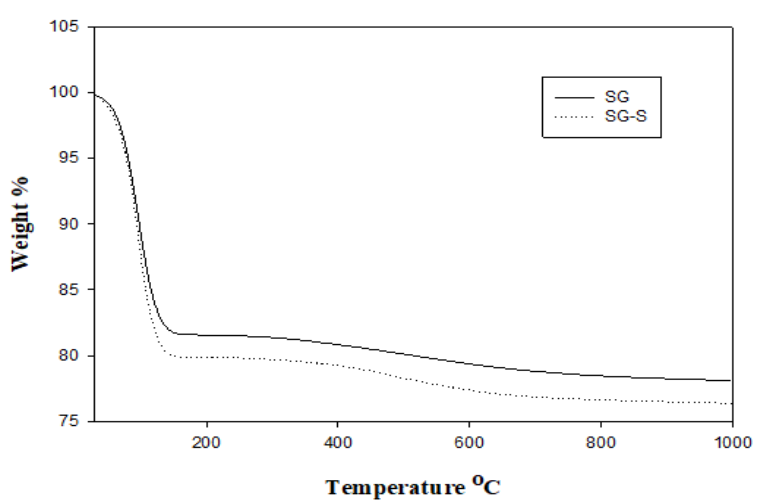

Fig. (5): Thermograms of $\mathrm{SG}_{\text {_. }}$ and $\mathrm{SG}_{(\text {Treated) }} \ldots . .$. in $\mathrm{N}_{2}$

Figure (7) illustrates partial spectra $\left(790-970 \mathrm{~cm}^{-}\right.$ ${ }^{1}$ ) of SG (A) and $\mathrm{SG}_{\text {(Treated) }}$ (B). A slight shift was observed in both peaks observed in this range. The peaks at 798 ( in both spectra, A and B) are assigned to $\mathrm{Si}-\mathrm{O}-\mathrm{Si}$ stretching vibration [43]. Moreover, the blue shift in the peak at 963.15 to $964.54 \mathrm{~cm}^{-1}$ can be attributed to the $-\mathrm{I}$ of the sulfonic gp [46].
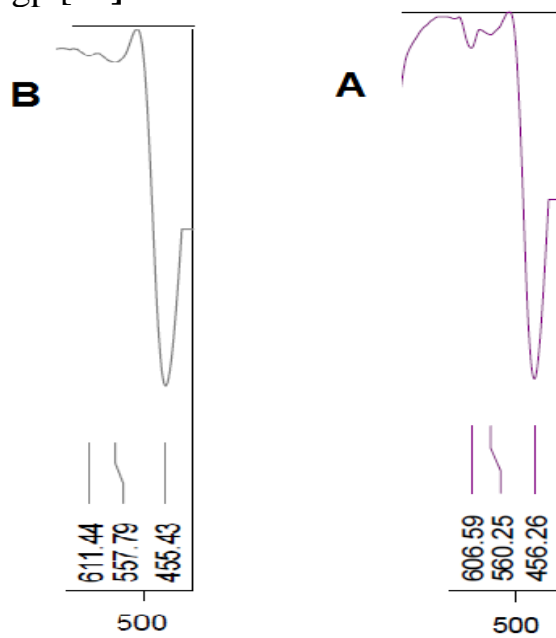

Fig. (6): Partial spectra $\left(450-620 \mathrm{~cm}^{-1}\right)$ of SG (A) and irradiated SG in the presence of $\mathrm{H}_{2} \mathrm{SO}_{4}(\mathrm{~B})$

Table (2): Peak hight ratio of 560/456 and 606/456 in the spectrum of SG (Fig.6A) and 557/455 and $611 / 455$ in the spectrum of $S G$ (Treated) (Fig.6B)

\begin{tabular}{cccc}
\hline $\begin{array}{c}\text { SG peak } \\
\text { ratio }\end{array}$ & $\begin{array}{c}\text { SG } \\
\text { (Treated) } \\
\text { peak ratio } \\
(557 / 455) \\
\text { (fig.6B) }\end{array}$ & $\begin{array}{c}\text { SG peak } \\
\text { ratio } \\
(606 / 455) \\
\text { (fig.6A) }\end{array}$ & $\begin{array}{c}\text { SG } \\
\text { (Treated) } \\
(611 / 455) \\
\text { (fig.6B) }\end{array}$ \\
\hline 0.058 & 0.089 & 0.092 & 0.072 \\
\hline
\end{tabular}


It should be mentioned that, SG peak ratio (963/798), in spectrum, Fig.(7A) (1.28), increased in spectrum,Fig.7B,(1.35) (Table3).

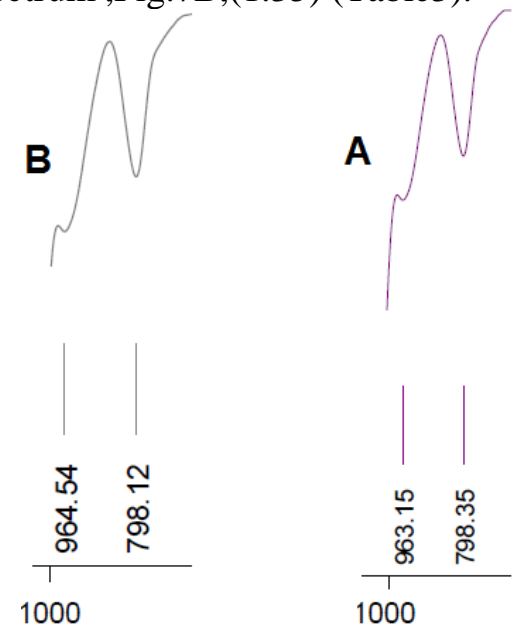

Fig. (7): Partial spectra $\left(790-970 \mathrm{~cm}^{-1}\right)$ of SG (A) and $\mathbf{S G}_{\text {(Treated) }}(\mathrm{B})$

Table (3): Peak height ratio of $963 / 798$ in the spectrum of SG (Fig. 7A) and 964/798 in the spectrum of $S G_{(\text {Treated) }}$ (Fig. 7B)

\begin{tabular}{cc}
\hline $\begin{array}{c}\text { SG peak ratio } \\
(963 / 798)\end{array}$ & $\begin{array}{c}\mathrm{SG}_{\text {(Treated) }} \text { peak ratio } \\
(964 / 798)\end{array}$ \\
$($ Fig.7A) & $($ Fig.7B) \\
\hline 1.28 & 1.35 \\
\hline
\end{tabular}

However, characteristic peaks of the $-\mathrm{SO}_{3} \mathrm{H}$ group are located in 1000-1100 $\mathrm{cm}^{-1}$ [47], which coincides with the enhanced appearance of the peak at $1067 \mathrm{~cm}^{-1}$,Where the band at $1067.66 \mathrm{~cm}^{-}$ ${ }^{1}$ (Fig.8) can be assignment to $\mathrm{S}=\mathrm{O}$ symmetric stretching modes of sulfonic acid groups, substituted at SG[48].

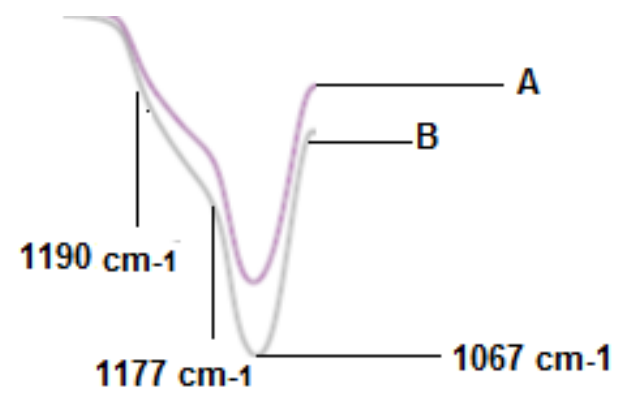

Fig. (8): Partial spectra $\left(900-1200 \mathrm{~cm}^{-1}\right)$ of SG (A) and $\mathbf{S G}_{\text {treated }}(B)$.

Also, the sholder (1170-1190 $\left.\mathrm{cm}^{-1}\right)$ can be attributed to the presence of sulfonic groups $(\mathrm{SOH}$ bend) $[49,50]$. Where, a doubly degenerate asymmetric stretch $\mathrm{SO}_{3}$ between 1123 and $1302 \mathrm{~cm}^{-1}$ is observed [50].

Figure (9) illustrates the blue shift of peak at $1984.91 \mathrm{~cm}^{-1}$, due to association of $\mathrm{H}_{2} \mathrm{O}$ [51], in partial spectrum 9A, to $1987.46 \mathrm{~cm}^{-1}$ in partial spectrum 9B. The band at 1987. $46 \mathrm{~cm}^{-1}$ can be assigned to the presence of hydroxonium/bisulfate on the SG surface [50]. Figure(10) shows that, both $\mathrm{SG}(\mathrm{A})$ and $\mathrm{SG}_{\text {(Treated) }}(\mathrm{B})$ exhibited a very broad peak at $3200-3600 \mathrm{~cm}^{-1}$, which resulted from the SiO-H vibration [43]. The shift of the broad band from $3262.56 \mathrm{~cm}^{-1}$ before treatment of $\mathrm{SG}$ (due to asymmetric and symmetric $\mathrm{O}-\mathrm{H}$ stretches) to $325450 \mathrm{~cm}^{-1}$ after treatment, can be attributed to the hydrophilicity of sulfonic group attached on the surface of SG [52]. Where, O-H streching vibration will be red shifted via strong hydrogen bonding [53] of the hydroxyl groups with the sulfonic group on the surface of SG. It can be proposed that hydrogen bonding between hydroxyl groups and sulfonic group is stronger than mutual hydrogen bonding of hydroxyl groups. 


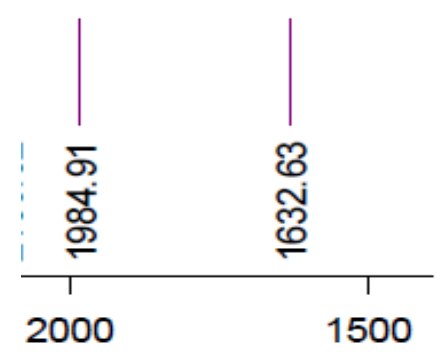

A

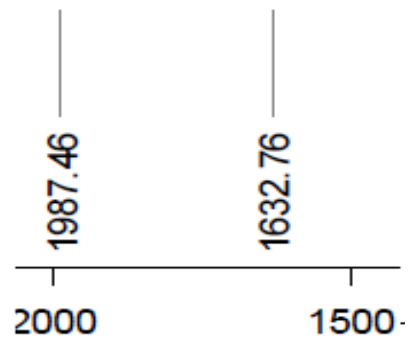

B

Fig. (9): Partial spectra $\left(2000-1500 \mathrm{~cm}^{-1}\right)$ of SG (A) and $\mathrm{SG}_{\text {(Treated) }}(\mathrm{B})$.
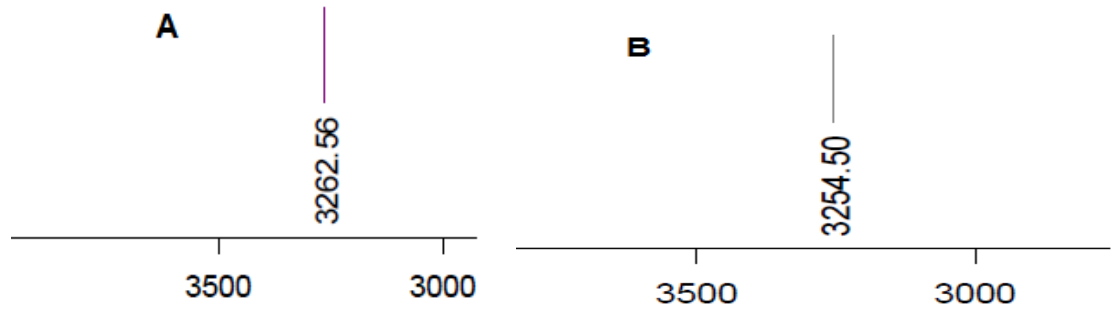

Fig. (10): Partial spectra $\left(3500-3000 \mathrm{~cm}^{-1}\right)$ of $\mathrm{SG}(\mathrm{A})$ and $\mathrm{SG}_{(\text {Treated }}(\mathrm{B})$

\section{Mechanism of sulfonation of SG surface}

Radiolysis of $\mathrm{H}_{2} \mathrm{SO}_{4}$ was studied by several authors $[46,54,54 \mathrm{a}, 55]$. It was proposed that the main radiatiolysis products of $\mathrm{H}_{2} \mathrm{SO}_{4}$ are $\mathrm{H}_{2} \mathrm{O}$, $\mathrm{SO}_{2}, \quad\left(\mathrm{~S}_{2} \mathrm{O}_{3}\right)_{\mathrm{x}}, \mathrm{H}_{3} \mathrm{O}^{+}, \mathrm{HSO}_{4}^{-}, \quad$ and $\mathrm{SO}_{4}{ }^{2-}\left[\begin{array}{ll}54\end{array}\right]$. Loeffler et al. [54] proposed that, excited $\mathrm{H}_{2} \mathrm{SO}_{4}$ $\left(\mathrm{H}_{2} \mathrm{SO}_{4}{ }^{*}\right)$ is formed upon radiolysis, which can be followed by ionization:

$$
\begin{gathered}
\mathrm{H}_{2} \mathrm{SO}_{4 \mathrm{ww} \rightarrow} \mathrm{H}_{2} \mathrm{SO}_{4}{ }^{*} \\
\mathrm{H}_{2} \mathrm{SO}_{4 \mathrm{ww} \rightarrow} \mathrm{H}_{2} \mathrm{SO}_{4}{ }^{+}+\mathrm{e}-
\end{gathered}
$$

Formation of $\mathrm{SO}_{3}$ can take place via dissociation $\begin{array}{llll}\text { of } & \text { excited } & \mathrm{H}_{2} \mathrm{SO}_{4} & \left(\mathrm{H}_{2} \mathrm{SO}_{4}{ }^{*}\right)\end{array}$ and $\mathrm{H}_{2} \mathrm{SO}_{4}{ }^{+}$recombination with an electron (eqs. 3,4 ):

$$
\begin{aligned}
& \mathrm{H}_{2} \mathrm{SO}_{4}{ }^{*} \rightarrow \mathrm{H}_{2} \mathrm{O}+\mathrm{SO}_{3} \\
& \mathrm{H}_{2} \mathrm{SO}_{4}{ }^{+}+\mathrm{e}-\rightarrow \mathrm{H}_{2} \mathrm{O}+\mathrm{SO}_{3}
\end{aligned}
$$

Formation of $\mathrm{SO}_{2}$ was, also, proposed via some reaction with bisulfite $\left(\mathrm{HSO}_{3}\right)$

radicals:

$$
\begin{gathered}
\mathrm{H}_{2} \mathrm{SO}_{4}{ }^{*} \rightarrow \mathrm{OH}+\mathrm{HSO}_{3} \\
\mathrm{H}+\mathrm{HSO}_{3} \rightarrow \mathrm{H}_{2} \mathrm{O}+\mathrm{SO}_{2}
\end{gathered}
$$

Moreover, Radical disproportionation involving $\mathrm{HSO}_{3}$ can form $\mathrm{SO}_{2}$ :

$$
\mathrm{HSO}_{3}+\mathrm{HSO}_{3} \rightarrow \mathrm{H}_{2} \mathrm{SO}_{4}+\mathrm{SO}_{2}
$$

Such radicals could combines with $\mathrm{OH}$ radical forming bisulfite radical:

$$
\mathrm{OH}+\mathrm{SO}_{2} \rightarrow \mathrm{HSO}_{3}
$$

On the other hand, radolysis of SG [56] can be illustrated in the following reactions: 


$$
\begin{aligned}
& \mathrm{SG}_{\mathrm{ww} \rightarrow} \mathrm{SG}^{*} \\
& \mathrm{SG}_{\mathrm{ww} \rightarrow} \mathrm{SG}^{+}(+\mathrm{eV} \text { hole })+\mathrm{e}-
\end{aligned}
$$

Where, $\mathrm{SG}^{*}$ represents excited SG.

Energy deposition in SG appears in the aqueous phase as solvated electrons. On the other hand, holes remain trapped in the silica phase. Oxidation of $\mathrm{OH}^{-}$by the +ve hole (in the surface of irradiated $\mathrm{SG})$ produce the hydroxyl radical $(\cdot \mathrm{OH})[57]$ :

$$
\mathrm{OH} \quad{ }^{-}+{ }^{+} \text {ve } \quad \text { hole }\left(\mathrm{h}^{+}\right) \rightarrow
$$

$\mathrm{OH}$

The $\mathrm{OH}$ radicals produced from eq (11) can participate in (eq.8), through which $\mathrm{HSO}_{3}$ radicals are produced. Moreover, exciton (excited electron and a hole in the valence band remain bound together) can participate in the formation of $\mathrm{SiO}$ [58]:

$$
{ }^{3} \text { exciton }+\mathrm{SG}-\mathrm{OH} \rightarrow \mathrm{SG}-\mathrm{O}+\mathrm{H}
$$

Where, ${ }^{3}$ exciton; represents triplet state exciton and SG-OH represents silanol group on surface of SG. It was proposed that, this surface effect decreases as the size of the SG particle size increases [58].

It was ,also, suggested that positive holes can react with SG-OH groups to give SG-O [58]:

$$
\mathrm{SG}-\mathrm{OH}+{ }^{+} \text {ve hole }\left(\mathrm{h}^{+}\right) \rightarrow \mathrm{SG}-\mathrm{O} \cdot+\mathrm{H}^{+}
$$

Therefore, sulfonation of SG surface can be carried out via combination of $\mathrm{HSO}_{3}$ radical (formed from eqs $(5,8)$ with $\mathrm{SiO}$. (formed from eqs 12,13 ) on the SG surface(eq.14):

$$
\mathrm{SiO}+\mathrm{HSO}_{3} \rightarrow \mathrm{SiO}-\mathrm{HSO}_{3}
$$

Aslo, $\mathrm{SiO}-\mathrm{HSO}_{3}$ can be formed by the reaction of SG-O (from eq. 12,13 ) with $\mathrm{SO}_{3}$ (from eq. 3,4 ):

$$
\begin{gathered}
\mathrm{SiO}+\mathrm{SO}_{3} \rightarrow{\mathrm{SiO}-\mathrm{SO}_{3}}^{\circ} \\
\mathrm{H}+\mathrm{SiO}_{-} \mathrm{SO}_{3} \rightarrow \mathrm{SiO}_{-} \mathrm{HSO}_{3}
\end{gathered}
$$

Finally, it should be mentioned that $\mathrm{H}$ atoms, which are formed during radiolysis, such as from eq.12, can induce rupture of $\mathrm{Si}-\mathrm{O}$ bonds [25a] and, consequently, the appearance of many segments of SG in SEM images (Fig.1).

\section{Conclusion}

Silica surface is considered to be covered with a monolayer of silanol groups. Therefore, the expected radiation-induced reaction of sulfuric acid with SG will be happened on the surface only. EDX scanning confirms the presence of sulfur on the surface of $\mathrm{SG}_{(\text {Treated) }}$. Moreover, images of both SG and SG treated reveal that, irradiation of SG in the presence of $\mathrm{H}_{2} \mathrm{SO}_{4}$ leads to a partial segmentation of $\mathrm{SG}$ particles. Quantitative scanning of the $\mathrm{SG}_{\text {(Treated) }}$ shows that $\mathrm{S} \%$ and $\mathrm{O} \%$ are affected by particle size of $\mathrm{SG}_{\text {(Treated). }}$ It was found that as particle size decreases from " $>0.2 \mathrm{~mm}-\leq 0.5 \mathrm{~mm}$ " to" $>0.16 \mathrm{~mm}$ - $0.2 \mathrm{~mm} ", \mathrm{~S} / \mathrm{O} \%$ increases. Further decrease in particle $\operatorname{size}(\leq 0.16 \mathrm{~mm})$ leads to a significant decrease in $\mathrm{S} / \mathrm{O} \%$. Which is attributed to the spontaneously adherence of SG particles together by cohesive forces. Consequently, the available surface area for reaction with sulfuric acid will decrease. The effect of absorbed radiation dose on $\mathrm{S} / \mathrm{O} \%$ was found to increase linearly as the absorbed dose increases up to $79.6 \mathrm{kGy}$,in the case of ps $>0.16 \mathrm{~mm}-0.2 \mathrm{~mm}$. Further absorbed dose increase, will lead to a significant decrease of $\mathrm{S} / \mathrm{O} \%$. This observation can be attributed to the destructive effect of $\gamma$-radiation on the sulfonated SG.

Comparison of the thermal stability of SG and $\mathrm{SG}_{\text {(Treated) }}$ reveals that the 1st weight loss (around $100^{\circ} \mathrm{C}$, due to physically adsorbed water) is different. So, in the range, $\mathrm{rt}-100{ }^{\circ} \mathrm{C}$ (in air) the weight loss of SG (\%) is higher than that of $\mathrm{SG}_{\text {(Treated) }}(\%)$. Which can be related to that, water is strongly hold on $\mathrm{SG}_{(\text {Treated }}$ relative to $\mathrm{SG}$. Where, sulfonation increases the hydropholicity of the surface. Therefore, the amount of desorbed water may be taken as evidence of the success of the sulfonation of SG. Above $200^{\circ} \mathrm{C}$ and up to $800{ }^{\circ} \mathrm{C}$ the weight loss can be attributed for the loss of strongly bonded water to sulfonic groups and the oxidative decomposition of sulfonic groups. Obove $800{ }^{\circ} \mathrm{C}$ the slow and continuous weight loss was due to the condensation of vicinal silanol groups leaving siloxane groups. The DSC analyses for $\mathrm{SG}_{\text {treated }}$ showed endo- and exothermic peaks consistent with the thermal loss behavior in the TGA analyses. DSC thermogram illustrates three endothermic peaks, which related to the two 
weight loss stages of TGA analyses. So, the $1^{\text {st }}$ strong DSC endothermic peak around $100^{\circ} \mathrm{C}$ confirms the loss of physiosorbed water. The 2 nd weak and broad endothermic peak in the range $250-480{ }^{\circ} \mathrm{C}$ can be attributed for the loss of strongly bonded water to sulfonic groups. An exothermic weak and broad peak in the range $>$ $480-<800{ }^{\circ} \mathrm{C}$, can be assigned to the decomposition of sulfonic groups. The $3^{\text {rd }}$ endothermic peak, centered at $900{ }^{\circ} \mathrm{C}$ may point to a chemical reaction(s) between remaining sulfonic and silanol groups. It is worth to mention that the final residues, after heating samples up to $1000{ }^{\circ} \mathrm{C}$ in air, reveal that the total weight loss in the case of $\mathrm{SG}$ is $21 \%$, while that of $\mathrm{SG}_{\text {(Treated) }}$ is $18 \%$. Interestingly, in $\mathrm{N}_{2}$ atmosphere, the total weight loss is higher in the case of $\mathrm{SG}_{\text {(Treated) }}$ (23.65\%) relative to that of $\mathrm{SG}(21.92 \%)$, which is contrary to the corresponding results in air atmosphere. Accordingly TGA of both SGand $\mathrm{SG}_{\text {(Treated) }}$ are affected by the atmosphere gas (air and $\mathrm{N}_{2}$ ) which reveal the role of $\mathrm{O}_{2}$ on the $\mathrm{SG}_{\text {(Treated) }}$ thermal degradation.

A comparative investigation, on the IR spectra of $\mathrm{SG}$ and $\mathrm{SG}_{\text {(Treated) }}$, reveals a difference in fingerprint region, and blue and red shift all over the spectra. Moreover, a relative variation in the peak heights was also observed upon such comparison. Peaks which indicate the presence of sulfonic group on the SG surface, can be observed in the $\mathrm{SG}_{\text {(Treated) }}$. It should be mentioned that direct sulfonation of SG by ionizing radiation rout has not been studied before.

Our results seem to be promising, where the procedure of radiation induced formation of " $\mathrm{SiO}_{2}$ $\mathrm{SO}_{3} \mathrm{H}^{\prime \prime}$ is easier than conventional methods. Further experiment should be carried to improve the radiation chemical yield of " $\mathrm{SiO}_{2}-\mathrm{SO}_{3} \mathrm{H}$ ".

\section{References}

1. Maria Stepanova, Steven Dew (2012): "Nanofabrication: Techniques and Principles". Springer Science, p163.

2. Q. Huo, D. I. Margolese, and Stucky, G. D. (1996). "Surfactant Control of Phases in the Synthesis of Mesoporous Silica-Based Materials".Chem. Mater., 8, 1147-1160.

3. Babonneau, F., Leite, L. and Fontlupt, S. (1999). "Structural characterization of organically-modified porous silicates synthesized using CTA+ surfactant and acidic conditions". J. Mater. Chem., 9, 175-178.

4. Young-Kwon Oh, Lan-Young Hong, Yamini Asthana, and Dong-Pyo Kim (2006). "Synthesis of Super-hydrophilic Mesoporous Silica via a Sulfonation”. Route . J. Ind. Eng. Chem.,12 (6),911-917.

5. Bougrin, K., Soufiaoui, M.,(1995). "Progress in Catalysis Research". Tetrahedron Lett., 36, 3683-3686.

6. Princy Gupta, Vineet Kumar and Satya Paul (2010). "Silica Functionalized Sulfonic Acid Catalyzed One-Pot Synthesis of 4,5,8aTriarylhex-ahydropyrimido[4,5-d]pyrimidine2,7 $(1 \mathrm{H}, 3 \mathrm{H})$-diones under Liquid Phase Catalysis”. J. Braz. Chem. Soc., 21(2) 349-354.

7. Mohammad Ali Zolfigol, Elahe Madrakian and Ezat Ghaemi (2002). "Silica Sulfuric Acid/ NaNO2 as a Novel Heterogeneous System for the Nitration of Phenols under Mild Conditions". Molecules, 7, 734-742.

8. Amin Rostami, Arash GhorbaniChoghamarani, Bahman Tahmasbi, Farasat Sharifi, Yahya Navasi, Darush Moradi (2017). "Silica sulfuric acid-coated $\mathrm{Fe}_{3} \mathrm{O}_{4}$ nanoparticles as high reusable nanocatalyst for the oxidation of sulfides into sulfoxides, protection and deprotection of hydroxyl groups using HMDS and $\mathrm{AC}_{2} \mathrm{O}$ ". Journal of Saudi Chemical Society, 21(4), 399-407.

9. Amir Landarani-Isfahani, Javad Safari, Marziyeh Ghotbinejad, Soheyla GandomiRavandi, Moshtael (2009). "Silica sulfuric acid (SSA) a novel catalyst for synthesis of some phenylhydrazone-2-ketomethylquinolines". Org. Chem. An Indian J.,5,39-42.

10. Zolfigol, M. A. (2001). "Silica sulfuric acid/NaNO2 as a novel heterogeneous system for production of thionitrites and disulfides under mild conditions". Tetrahedron, 57, 9509-9511.

11. Khodabakhsh Niknam, Dariush Saberi and Maleki Mohagheghnejad (2009). "Silica Bonded S-Sulfonic Acid: A Recyclable Catalyst for the Synthesis of Quinoxalines at Room Temperature". Molecules, 14, 19151926.

12. Wilson, K., Lee, A.F., Macquarrie, D.J.,Clark, J.H. (2002). "Structure and reactivity of solgel sulphonic acid silicas". Appl. Catal. A, 228, 127-133.

13. Melero,J.A., Grieken,R.V.,Morales, G. (2006). "Advances in the Synthesis and Catalytic Applications of Organosulfonic-Functionalized Mesostructured Materials". Chem. Rev., 106, 3790-3812.

14. Hari, G. Sri , Nagaraju ,M. , and Marthanda Murthy, M. (2007). "Silica Sulfuric Acid- 
Catalyzed Friedel-Crafts Alkylation of Indoles with Nitro Olefins". Synthetic Communications,38(1),100-105.

15. Mukesh Kumar Yadav, Ajay Vinod Kothari, Dhananjay G. Naik, and Virendra Kumar Gupta (2009). "Morphological silica-supported acid catalyst for esterification of aliphatic fatty acid". Green Chemistry Letters and Reviews, 2(3),181-187.

16. Zolfigol MA, Madrakian E, Ghaemi E. (2002). "Silica Sulfuric Acid/ $\mathrm{NaNO}_{2}$ as a Novel Heterogeneous System for the Nitration of Phenols under Mild Conditions". Molecules,7(10),734-742.

17. Farhad Shirini, Mohammad Ali Zolfigol, and Kamal Mohammadi (2004). "Silica Sulfuric Acid as a Mild and Efficient Reagent for the Acetylation of Alcohols in Solution and under Solvent Free Conditions". Bull. Korean Chem. Soc.,25(2),325-327.

18. Mohammad Ali Zolfigol, Gholamabbas Chehardoli, Mina Dehghanian, Khodabakhsh Niknam, Farhad Shirinid and Ahmad Khoramabadi-Zada (2008). "Silica Sulfuric Acid and $\mathrm{Al}\left(\mathrm{HSO}_{4}\right)_{3}$ : As Efficient Catalysts for the Formylation of Alcohols by Using Ethyl Formate under Heterogeneous Conditions". Journal of the Chinese Chemical Society, 55, 885-889.

19. Ghodsi Mohammadi ZiaraniZeinab DashtianehMonireh Shakiba NahadAlireza Badie(2015). Arabian Journal of Chemistry, $\underline{8(5)}, 692-697$.

20. Joshi, U. J, Gokhale, K. M., Kanitkar, A. P., (2011). Sulphonation of Aromatics using Silica Sulphuric acid/ NaHSO4 as a Novel Heterogeneous System at Ambient Temperature.

Int.J.Pharm.Phytopharmacol.Res., ～1(3),102106.

21. Tzvetkova1, P., Nickolov, R.,(2012). "Modified and Unmodified Silica Gel used for Heavy Metal Ions Removal from Aqueous Solutions". Journal of the University of Chemical Technology and Metallurgy, 47(5)498-504.

22. Mahmoud O. Abd El-Magied, Abdel Ghaffar S.A. Soliman, Abd Allah M. Abd El-Hamid, Ekramy M. Eldesouky (2018). "Uranium extraction by sulfonated mesoporous silica derived from blast furnace slag". J. Nucl. Mater.,509, 295-304.

23. Hirokazu Munakata, Hiroto Chiba, Kaoru Dokko, Jun-ichi Hamagami (2006). "Enhancement on Proton Conductivity of Three-Dimensionally Ordered Macroporous
Silica Membrane by Surface Sulfonation”. Key Engineering Materials, 301,143-146.

24. Chang-Chun Ke, Xiao-Jin Li, Qiang Shen, Shu-Guo Qua, Zhi-Gang Shao, Bao-Lian Yi,(2011).Investigation on sulfuric acid sulfonation of in-situ sole gel derived Nafion/SiO2 composite membrane. international journal of hydrogen energy, 36, 3606-3613.

25. 25.- Hossein Beydaghi , Mehran Javanbakht ,Alireza Badiei (2014). Cross-linked poly (vinyl alcohol)/sulfonated nanoporous silica hybrid membranes for proton exchange membrane fuel cell. J Nanostruct Chem.,4,97105.

26. (25a). Al-Moatasem El-Sayed, Matthew B. Watkins, Tibor Grasser, Valery V. Afanas'ev, and Alexander L. Shluger(2015). HydrogenInduced Rupture of Strained $\mathrm{Si}-\mathrm{O}$ Bonds in Amorphous Silicon Dioxide. Physical Review Letters, 114, 115503.

27. Chapter 5: Silica Gels and Powders, https://docplayer.net/6959673-Chapter-5silica-gels-and-powders.html. p. 462.

28. Li Cuia, Qing Geng, Chunli Gong, Hai Liu, Genwen Zheng,Guangjin Wang, Qiming Liuc and Sheng Wen (2015). "Novel sulfonated poly (ether ether ketone)/silica coated carbon nanotubes highperformance composite membranes for directmethanol fuel cell". Polym. Adv. Technol., 26, 457-464.

29. Hassan S. Ghaziaskar, Yadollah M. Gorji, (2018). Synthesis of solketalacetin as a green fuel additive via ketalization of monoacetin with acetone using silica benzyl sulfonic acid as catalyst. Biofuel Research Journal, 17, 753758.

30. A method and apparatus for producing a peroxyacid solution-WO2005016511A1 PCT.

31. https://en.wikipedia.org/wiki/Peroxydisulfuric acid

32. Sung-Mi Park, Young-Woo Choi, Tae-Hyun Yang, Jin-Soo Park, and Sung-Hyun Kim (2013). "A study on sulfonated poly(arylene ether sulfone) membranes containingtwo different types of $\mathrm{SiO} 2$ for a high temperatureand low-humidified polymer electrolyte fuel cell". Korean J. Chem. Eng., 30(1), 87-94.

33. Musso, G. E., Bottinelli,E., Celi, L., Magnaccaa, G. and Berlier, G.,( 2015). Influence of surface functionalization on the hydrophilic character of mesoporous silica nanoparticles. Phys.Chem.Chem.Phys., 17, 13882-13894.

34. Young-Kwon Oh, Lan-Young Hong, Yamini Asthana, and Dong-Pyo Kim(2006). Synthesis

Arab J. Nucl. Sci. \& Applic. Vol. 53, No. 4 (2020) 
of Super-hydrophilic Mesoporous Silica via a Sulfonation Route . J. Ind. Eng. Chem.,12(6),911-917.

35. Oh, Y. K., Leng yan Hong, Yamini Asthana, Dongpyo Kim, (2006). Journal of Industrial and Engineering Chemistry, 12(6), 911-917.

36. Deuk Ju Kim, Seung Moon Woo, and Sang Yong Nam (2012). Properties of SPAES/Phosphotungsticacid/Sulfonated Silica Composite Membranes Prepared by the In situ and Sol-Gel Process. Macromolecular Research, 20(10), 1075-1082.

37. Shimoaka, T., Wakai, C., Sakabe, T., Yamazaki, S. and Hasegaw, T.( 2015). Hydration structure of strongly bound water on the sulfonic acid group in a Nafion membranestudied by infrared spectroscopy and quantum calculation. Phys.Chem.Chem.Phys.,

38. 17, 8843- 8849 .

39. Abdel-Hady E.E., Abdel-Hamed MO and Gomaa M.M.(2013). Preparation and Characterization of Commercial Polyethyleneterephthalate Membrane for Fuel Cell Applications. J. Membrane Science and Technology 3(122), 2,DOI:10.4172/21559589.1000122.

40. Yehia El-Naggar, (2013).Thermal Analysis of the Modified and Unmodified Silica Gels to Estimate their Applicability as Stationary Phase in Gas Chromatography. Journal of Emerging Trends in Engineering and Applied Sciences (JETEAS), 4(1), 144-148.

41. Middlebrook, A. M., Iraci, L. T., McNeill, L. S., Koehler, B. G., Wilson, M. A., Saastad, O. W. and Tolbert, M. A.,(1993). "Fourier transform-infrared studies of thin $\mathrm{H}_{2} \mathrm{SO}_{4} / \mathrm{H}_{2} \mathrm{O}$ films: Formation, water uptake, and solidliquid phase changes". J. Geophys.Res., 98, 20473- 20481.

42. Walrafen, G. E. and Dodd, D. M., (1961). "Infra-red absorption spectra of concentrated aqueous solutions of sulphuric acid. Part 2.$\mathrm{H}_{2} \mathrm{SO}_{4}$ and $\mathrm{HSO}_{4}^{-}$vibrational fundamentals and estimates of $\left(F_{298 \cdot 15}^{\circ}-H_{0}^{\circ}\right) / T$ and $S_{298 \cdot 15}^{\circ}$ for $\mathrm{H}_{2} \mathrm{SO}_{4}$ gas". Trans. Faraday. Soc., 57,1286-1296.

43. Gigue`re, P. A. and Savoie, R.,(1960). Les Spectres Infrarouges De L'Acide Sulfurique et Des Oleums. Can. J. Chem., 38, 2467-2476.

44. Zongli Xie, Buu Dao, Jonathan Hodgkin, Manh Hoang, Anita Hill, Stephen Gray(2011). Synthesis and characterization of hybrid organic-inorganic materials based on sulphonated polyamideimide and silica. J. Polym. Res., 18, 965-973.
45. Nariyal, R. K., Kothari, P., Bisht, B.,( 2014). FTIR Measurements of $\mathrm{SiO}_{2}$ Glass Prepared by Sol-Gel Technique. Chemical Science Transactions, 3(3), 1064-1066.

46. Nathalie A. Cabrol, and Edmond A. Grin,(2018). Remote Detection of Phyllosilicates on Mars and Implications for Climate and Habitability. Chapter 3 - "From Habitability to Life on Mars",p46.

47. vibea- Hema Tresa Varghese, Yohannan Panciker, C.,Madhava Warrier, G., Manikantan Nair and Raju, K., (2009).Vibrational Spectroscopic Studies and $\mathrm{Ab}$ Initio Calculations of p-Chlorobenzenesulfonic Acid. Int. J. Chem. Sci., 7(4), 2278-2284.

48. Sibirskaya, G. K. and A. K. Pikaev (1967). The Radiolysis of Aqueous Sulfuric Solutions of Methyl Alcohol. Izvestiya Akademii Nauk SSSR, Seriya Khimicheskaya, No. 1, pp. 190192.

49. Chang-Chun Ke, Xiao-Jin Li, Qiang Shen, Shu-Guo Qua, Zhi-Gang Shao Bao-Lian Yi,(2011).Investigation on sulfuric acid sulfonation of in-situ sole gel derived Nafion/SiO2 composite membrane. international journal of hydrogen energy, 36, 3606-3613.

50. Patricia Valle-Vigón, Marta Sevilla and Antonio B. Fuertes (2012). Sulphonated mesoporous silica-carbon composites and their use as solid acid catalysts. Applied Surface Science, 261, 574-583.

51. Hema Tresa Varghese, Yohannan Panciker, C., Madhava Warrier, G., Manikantan Nair and Raju, K.,(2009) Vibrational Spectroscopic Studies and ab Initio Calculations of $\mathrm{p}$ Chlorobenzenesulfonic Acid. Int. J. Chem. Sci.,7(4), 2278-2284.

52. Andrew B. Horn and Jessica Sully, K.,(1999). ATR-IR spectroscopic studies of the formation of sulfuric acid and sulfuric acid monohydrate films. Phys. Chem. Chem.,1(16)3801- 3806.

53. Alfred A. Christy and Per K. Egeberg (2005). "Quantitative determination of surface silanol groups in silicagel by deuterium exchange combined with infrared spectroscopy and chemometrics". Analyst, 130, 738-744.

54. Isabel Zamanillo Lopez (2015). "Hybrid membranes for fuel cell Materials". Université Grenoble Alpes,. www.semanticscholar.orgp.66

55. Yukihiro Ozaki، Marek Januz Wójcik، Jürgen Popp (2019). Molecular Spectroscopy, 2 Volume Set: A Quantum Chemistry Approach. John Wiley \& Sons.p406. 
56. Loeffler, M.J. , Hudson, R.L. , Moore, M.H. , Carlson ,R.W., (2011). "Radiolysis of sulfuric acid, sulfuric acid monohydrate, and sulfuric acid tetrahydrate and its relevance to Europa". Icarus, Volume 215, Issue 1, September, 370380.

57. (54a) Jun Ma, Uli Schmidhammer,Mehran Mostafavi (2014). Picosecond Pulse Radiolysis of Highly Concentrated Sulfuric Acid Solutions: Evidence for the Oxidation Reactivity of Radical Cation $\mathrm{H}_{2} \mathrm{O}^{\cdot+}$.J. Phys. Chem. A, 118, 23, 4030-4037.

58. 55. Yamada Reiji, Nagaishi Ryuji, Hatano Yoshihiko, Yoshida Zenko (2008)."Hydrogen production in the $\gamma$-radiolysis of aqueous sulfuric acid solutions containing $\mathrm{Al}_{2} \mathrm{O}_{3}, \mathrm{SiO}_{2}$, $\mathrm{TiO}_{2}$ or $\mathrm{ZrO}_{2}$ fine particles". International Journal of Hydrogen Energy, 33(3)929 - 936.

59. Hajime Ogura, Yoshio Tachika, Yasuo Suzuki , Chiyoko Nakazato,Masaharu Kondo , Takeshi Sawai and Teruko Sawai(1975). "Effect of Gamma Radiation on Silica Gel". Journal of Nuclear Science and Technology,3, 167-173.

60. Christensen,H., (1965). "Radiolysis of Aqueous Benzene Solutions in the Presence of Inorganic Oxides". Aktiebolaget Atomenergi Stockholm, Sweden, p8.

61. Sophie Le Caër (2011). Water Radiolysis: Influence of Oxide Surfaces on $\mathrm{H}_{2}$ Production under Ionizing Radiation. Water, 3, 235-253. 